\title{
Platinum-group element remobilisation and concentration in the Cliff chromitites of the Shetland Ophiolite Complex, Scotland
}

DOI:

10.1180/minmag.2017.081.108

\section{Document Version}

Accepted author manuscript

Link to publication record in Manchester Research Explorer

Citation for published version (APA):

O'Driscoll, B., Garwood, R., Day, J. M. D., \& Wogelius, R. A. (2018). Platinum-group element remobilisation and concentration in the Cliff chromitites of the Shetland Ophiolite Complex, Scotland. Mineralogical Magazine, 82(3), 471-490. https://doi.org/10.1180/minmag.2017.081.108

\section{Published in:}

Mineralogical Magazine

\section{Citing this paper}

Please note that where the full-text provided on Manchester Research Explorer is the Author Accepted Manuscript or Proof version this may differ from the final Published version. If citing, it is advised that you check and use the publisher's definitive version.

\section{General rights}

Copyright and moral rights for the publications made accessible in the Research Explorer are retained by the authors and/or other copyright owners and it is a condition of accessing publications that users recognise and abide by the legal requirements associated with these rights.

\section{Takedown policy}

If you believe that this document breaches copyright please refer to the University of Manchester's Takedown Procedures [http://man.ac.uk/04Y6Bo] or contact uml.scholarlycommunications@manchester.ac.uk providing relevant details, so we can investigate your claim.

\section{OPEN ACCESS}




\title{
Platinum-group element remobilisation and concentration in the Cliff chromitites of the Shetland Ophiolite Complex, Scotland
}

\author{
Brian O’Driscoll ${ }^{1}$, Russell Garwood ${ }^{1,2}$, James M.D. Day ${ }^{3}$, Roy Wogelius ${ }^{1}$ \\ ${ }^{1}$ School of Earth and Environmental Sciences, Oxford Road, University of Manchester, M13 9PL, UK \\ ${ }^{2}$ Department of Earth Sciences, Natural History Museum, Cromwell Road, London SW7 5BD, UK \\ ${ }^{3}$ Geosciences Research Division, Scripps Institution of Oceanography, UCSD, La Jolla, CA 92093-0244, USA
}

\begin{abstract}
The 492 Ma Shetland Ophiolite Complex (SOC) contains an extensive mantle section, within which numerous podiform chromitite bodies formed during melt percolation in a supra-subduction zone setting. One of the SOC chromitite localities has an unusual style of platinum-group element (PGE) mineralisation. Specifically, the Cliff chromitite suite has relatively high (>250 ppm) Pt plus $\mathrm{Pd}$, compared to other SOC chromitites. In this study, we apply petrographic observation, mineral chemistry and novel X-ray microtomography data to elucidate the petrogenesis of PGE-bearing phases at Cliff. The combined datasets reveal that the PGE at Cliff have likely been fractionated by an As-rich fluid, concentrating Pt and Ir into visible $(0.1-1 \mu \mathrm{m})$ platinum-group minerals (PGM) such as sperrylite and irarsite, respectively. The high $(>1 \mathrm{ppm})$ bulk rock concentrations of the other PGE (e.g., Os) in the Cliff chromitites suggests the presence of abundant fine-grained unidentified PGM in the serpentinised groundmass. The spatial association of arsenide phases and PGM with alteration rims on $\mathrm{Cr}$-spinel grains suggests that the high $\mathrm{Pt}$ and $\mathrm{Pd}$ abundances at Cliff result from a late-stage low-temperature (e.g., 200-300 ${ }^{\circ} \mathrm{C}$ ) hydrothermal event. This conclusion highlights the potential effects that secondary alteration processes can have on modifying and upgrading the tenor of PGE deposits.
\end{abstract}

\section{Introduction}

The platinum-group metals are high-value industrial commodities that concentrate naturally in select geological environments. In particular, ore deposits of the platinum-group elements (PGE: Os, Ir, Ru, Rh, Pt, Pd) are known from layered mafic-ultramafic intrusions and from the mantle sections of supra-subduction zone ophiolites. In many - but not all - of these occurrences, the PGE are hosted in chromitite seams (>60 vol.\% Cr-spinel). A significant body of work demonstrates the petrogenetic link between the concentration of the PGE and the formation of chromitite (e.g., Irvine 1977; Melcher et al. 1997; O’Driscoll et al. 2009; González-Jiménez et al. 2014a, 2014b; Latypov 
et al. 2013; Godel 2015). Layered intrusion-bearing 'stratiform' chromitite seams are associated with two of the largest deposits (reefs) of the PGE on Earth: the Merensky Reef and the UG-2 chromitite, both situated in the Critical Zone of the $\sim 2$ Ga Bushveld Complex (South Africa; cf. Schouwstra et al. 2000). However, podiform chromitites hosted in ophiolitic mantle may also contain significant enrichments of the PGE, up to economically viable grades (>20 ppm Pt, Pd). In contrast to layered intrusion-hosted PGE deposits which typically show high PPGE (Pt, Pd)/IPGE (Os, Ir, Ru, Rh) ratios, ophiolite PGE-rich deposits typically have low PPGE/IPGE (e.g., Page and Talkington 1984, Oshin and Crocket 1986, Melcher et al. 1997, O’Driscoll and González-Jiménez 2016; Fig. 1).

The mechanism(s) by which the PGE concentrate in the upper mantle, and the relationship between the petrological processes that form chromitite and the platinum-group minerals (PGM), are poorly constrained. In the majority of cases, base-metal sulphides are thought to play an important role by scavenging the PGE in upper mantle chromitite-forming magma conduits (cf. Holwell and McDonald 2010). This is because the PGE exhibit strongly chalcophile tendencies in terrestrial magmatic systems (i.e., partition coefficients up to $10^{6}$; Mungall and Brenan, 2014). However, evidence suggests that within cooling magmatic systems, the PGE only exist transiently in solid-solution in base-metal sulphides, and the PGM form during a complex down-temperature crystallisation process. Based on experimental data from the Fe-Ni-Cu-S system that have been used to examine PGE partitioning behaviour, Holwell and McDonald (2010) presented a model that proposed the partitioning of Os, Ir and Ru into Fe-Ni-S monosulphide solution (mss) that crystallised from base-metal sulphide liquid at high temperature $\left(\sim 1000^{\circ} \mathrm{C}\right)$. Platinum and $\mathrm{Pd}$ concentrate in the $\mathrm{Cu}$-rich liquid fraction that remains (referred to as intermediate solid solution; iss), with As, Bi, Te. Unmixing of the iss leads to the crystallisation of the platinum-group minerals (PGM), which are a diverse group of ( 135) alloys, sulphides, arsenides and other phases, that form as accessory minerals in these systems (O’Driscoll and González-Jiménez 2016). 
Critical gaps remain in our understanding of PGM petrogenesis. In particular, the degree to which low-temperature processes may modify the distribution of the PGE and form new PGM as subsolidus reaction products is unknown (cf. Hanley 2005). Some authors have suggested that desulphurisation may be a relevant process (e.g., Godel and Barnes 2008). Others have argued more generally for metasomatism as an important mechanism - if not in the primary concentration of the PGE in a rock, then through the dissolution, mobilisation and reprecipitation of the PGM. For example, Godel and Barnes (2008) highlight that PGE mobilisation has occurred in sulphides of the 2.7 Ga JM Reef (Stillwater Complex), during the Laramide Orogeny at 70-80 Ma. Similarly, studies carried out on the Platinova Reef of the Skaergaard suggest that its PGM assemblage equilibrated at temperatures as low as $300^{\circ} \mathrm{C}$ (Karup-Møller et al. 2008). Coggon et al. (2011) inferred that PGM compositions in the Merensky Reef were modified by a hydrothermal fluid after the crystallisation age of the reef (the latter age is constrained by $\mathrm{U}-\mathrm{Pb}$ in zircon). Thus, the whole rock budget of the PGE can potentially be modified and enhanced during metasomatism, so there are important economic implications for a better understanding of relatively low-temperature, as well as magmatic, ore-forming processes. Although ophiolite chromitites are not a significant contributor to the global PGE supply, these deposits offer different and potentially valuable perspectives on the petrogenesis of the PGM to that gained from the study of mid-upper crustal layered intrusions.

In this study, an anomalous upper mantle chromitite deposit from the Shetland Ophiolite Complex (SOC; Fig. 2) in northern Scotland was targeted to further interrogate the petrogenesis of PGM formation in upper mantle environments. The chromitite, from the locality of Cliff on the island of Unst (Fig. 2), is known for its exceptionally high levels of enrichment in the PPGE ( 250 ppm Pt+Pd, O’Driscoll et al. 2012; see also Prichard and Lord 1993). Unusually for ophiolite chromitite deposits, the PPGE are enriched by an order of magnitude over the IPGE (Fig. 1) such that the distribution of PGE overall is more similar to that from layered intrusions. Another intriguing feature of the Cliff PGE mineralisation is that it is associated with As-rich phases; there 
is little or no base metal sulphide in these rocks. Here, we combine X-ray microtomography $(\mu \mathrm{CT})$ with petrography and mineral chemistry to visualise the 3D distribution and microstructure of the base- and precious metal-rich phases and link this to their chemical signatures. Establishing the microstructural relationships between Cr-spinel, base-metal phases and the PGM in chromitite is pivotal to understanding the petrogenesis of these deposits; distinguishing between these high density phases is an objective particularly well-addressed by $\mu$ CT (e.g., Ketchum and Carlson 2001; Godel et al. 2010; Godel et al. 2013; Godel, 2015; Prichard et al. 2017). The key goal in this study is to elucidate the distribution of the PGE between specific carrier phases and link this to the chromitite microstructure and mineral chemistry to formulate a comprehensive petrogenetic interpretation.

\section{Geological setting}

The SOC is a 492 Ma ophiolite (Prichard 1985; Spray and Dunning 1991), thought to have been obducted onto Laurentia at $470 \mathrm{Ma}$ (Flinn et al. 1991; Chew et al. 2010). Although overlying components of the ophiolite are missing or not well-exposed (e.g., the sheeted dyke complex) on the islands of Unst or Fetlar, the mantle section is extensive and well-preserved (Derbyshire et al., 2013). Notably, a portion of mantle peridotite associated with pillow lavas, sediments and crosscutting dykes has been recognised on mainland Shetland. This has been linked to the SOC to the north by gravity and aeromagnetic anomalies, possibly representing an extensive sliver of Iapetus Ocean mantle (Day et al., 2017). At Unst and Fetlar, the mantle section predominantly comprises serpentinised harzburgite, with numerous dunite layers and lenses, and less abundant chromitites and pyroxenites (Fig. 2; Flinn 2001). Chromitite seams occur encased in dunite sheets and pods; a relationship that has previously been invoked to explain the formation of chromitite due to high degrees of melt-rock reaction in zones (channels) of focused melt flow (O’Driscoll et al. 2012; Derbyshire et al. 2013). This melt percolation is likely to have occurred in a mantle wedge 
environment, related to subduction of Iapetus lithosphere in a forearc setting (Crowley and Strachan 2015).

The petrological Moho is well-exposed on Unst, and the Cliff chromitite suite lies $\leq 1 \mathrm{~km}$ stratigraphically below its position, close to the trace of a structure (to the west) that probably excised the ophiolite sole thrust (Cutts et al. 2011). Harzburgites that host the Cliff chromitites yield mantle-like ${ }^{187} \mathrm{Os} /{ }^{188} \mathrm{Os}$ initial isotopic compositions at $492 \mathrm{Ma}$ (O’Driscoll et al. 2012). The Cliff chromitites are between 0.1-2 m thick and are structurally complex, occurring as stock-work veins and laterally discontinuous pods and lenses, mostly oriented sub-parallel to the petrological Moho (e.g., Derbyshire et al. 2013). We sampled material from pits dug within the Cliff chromitite suite in the 1800 s, which were used for producing yellow pigment from the chromitite.

\section{Analytical techniques}

Mineral chemistry

A JEOL JXA-8900RL electron microprobe at the University of Göttingen (Germany) was employed to make the back-scattered electron images of the Cliff chromitites, using a $20.0 \mathrm{kV}$ acceleration voltage and a $20 \mathrm{nA}$ beam current. The instrument settings and protocols have otherwise been previously outlined in Derbyshire et al. (2013), but the details of the arsenide and PGM measurements are summarised here. For the arsenide analyses, peak and background count times were $15 \mathrm{~s}$ and $5 \mathrm{~s}$, respectively, for $\mathrm{S}, \mathrm{Fe}$ and $\mathrm{Zn}, 30 \mathrm{~s}$ and $15 \mathrm{~s}$ peak and background, respectively, for $\mathrm{As}, \mathrm{Cu}, \mathrm{Ni}, \mathrm{Pb}, \mathrm{Sb}$ and $\mathrm{Co}$, and $60 \mathrm{~s}$ and $30 \mathrm{~s}$, respectively, for $\mathrm{Se}$ and $\mathrm{Te}$. A range of standards including $\mathrm{ZnS}$, AsGa, galena, gahnite and native metals and semi-metals $\mathrm{Te}, \mathrm{Cu}, \mathrm{Ni}$, $\mathrm{Se}, \mathrm{Sb}, \mathrm{Fe}$ and Co. For the PGM, count times of $15 \mathrm{~s}$ and $5 \mathrm{~s}$ were used for $\mathrm{S}, \mathrm{As}, \mathrm{Fe}, \mathrm{Si}, \mathrm{Ni}$, respectively; $30 \mathrm{~s}$ and $15 \mathrm{~s}$ for $\mathrm{Sb}, \mathrm{Cu}, \mathrm{Co}, \mathrm{Ru}, \mathrm{Ir}, \mathrm{Rh}$ and $\mathrm{Pt}$, respectively; $60 \mathrm{~s}$ and $30 \mathrm{~s}$ for $\mathrm{Pd}$ and Os, respectively. The standards used for the PGM analyses include $\mathrm{ZnS}$, AsGa, wollastonite and a range of native metals for $\mathrm{Sb}, \mathrm{Fe}, \mathrm{Cu}, \mathrm{Co}, \mathrm{Ru}, \mathrm{Pd}, \mathrm{Ni}, \mathrm{Ir}, \mathrm{Rh}, \mathrm{Os}$ and $\mathrm{Pt}$ calibration. Detection limits 
for PGE in the PGM are as follows: Ir: 592 ppm, Os: 2196 ppm, Ru: 237 ppm, Rh: 276 ppm, Pd: 276 ppm, Pt: 649 ppm (Derbyshire et al. 2013).

The laser ablation inductively coupled plasma mass spectrometry (LA-ICP-MS) data were collected at the time of the analytical campaign reported in O'Driscoll et al. (2012). In the Cliff samples, LA-ICP-MS analyses were carried out on Cr-spinel, arsenide and across host serpentinised matrix material (but not PGM, which are typically too small to be identified). The measurements were performed at the University of Maryland (USA) using a New Wave $213 \mathrm{~nm}$ wavelength laserablation system attached to a Thermo Fisher Element 2 ICP-MS. Trace-element abundances were determined on individual spots and raster paths using a variable laser beam diameter $(6-55 \mu \mathrm{m})$ and a laser repetition rate of $7 \mathrm{~Hz}$, at 1.4 to $2.5 \mathrm{~J} / \mathrm{cm}^{2}$. Argide and $\mathrm{Ni} / \mathrm{Cu}$ interferences were monitored during analysis and were found to be negligible. Ablation was conducted under a helium atmosphere to enhance production of fine aerosols and the ablated sample was mixed with argon prior to transport to the ICP-MS. Each analysis consisted of $60 \mathrm{~s}$ of data collection. Backgrounds on the ICP-MS sample gas were collected for approximately $20 \mathrm{~s}$ followed by approximately $40 \mathrm{~s}$ of laser ablation of the sample. Data were collected in time-resolved mode so that effects of inclusions, mineral zoning, and possible penetration of the laser beam to underlying phases could be evaluated for each analysis. Plots of counts per second versus time were examined for each analysis and integration intervals for the gas background and the sample analysis were selected manually. Each LA-ICP-MS analysis was normalised to a major-element oxide (typically Fe), measured by electron microprobe, as an internal standard to account for variable ablation yield. This internal normalisation is supported by the electron microprobe data, which allowed no more than $\sim 4 \%$ relative difference in $\mathrm{Ni}$ or $\mathrm{Cr}$ content over a $50 \mu \mathrm{m}$ spot and the LA-ICP-MS timeresolved patterns having shown that the ablated volumes were generally homogeneous. For all data, the NIST 610 glass standard was used for calibration of relative element sensitivities, using values from a compiled database of preferred values from GEOREM. Replicate LA-ICP-MS analyses of the University of Toronto JB Sulphide standard run at intervals during the analytical 
session, yielded an external precision of $1 \%$ ( $2 \sigma$ relative standard deviation) for all trace- and major-element compositions.

\section{$3 D$ image analysis by $X$-ray microtomography}

Hand specimen rock samples were investigated with laboratory-based microtomography in the Manchester X-ray Imaging Facility (MXIF, University of Manchester). Scans were conducted using a Nikon Metris 225/320 kV X-ray CT, within a customised bay, and with a 2000x2000 Perkin Elmer 1621-16-bit amorphous silicon flat-panel detector. All scans used 3142 projections, a tungsten reflection target, with the following variable settings:

- $1000 \mathrm{~ms}$ exposure, unfiltered source at $115 \mathrm{kV}$ and $60 \mu \mathrm{A}$, giving a voxel size of $32.8 \mu \mathrm{m}$.

- $1000 \mathrm{~ms}$ exposure, source at $200 \mathrm{kV}$ and $75 \mu \mathrm{A}$ with a $0.5 \mathrm{~mm}$ copper filter, giving a voxel size of $35.2 \mu \mathrm{m}$.

- $708 \mathrm{~ms}$ exposure, source at $130 \mathrm{kV}$ and $120 \mu \mathrm{A}$ with a $0.5 \mathrm{~mm}$ copper filter, giving a voxel size of $45.1 \mu \mathrm{m}$.

In order to interrogate the distribution of the small volumes of arsenide and PGM inclusions, higher resolution data were collected at the Diamond Light Source (DLS) synchrotron (UK). The high flux - in part achieved by using a pink beam - of beamline I13 facilitated successful scans at 1.1 micron voxel size, despite relatively $\mathrm{X}$-ray dense samples. Approximately $1 \mathrm{~mm}$ diameter cores were drilled from hand specimens. These were mounted using glue to the tip of the metal pin on a magnetic sample holder. Specimens were scanned using a pink beam, with a $3 \mathrm{~mm}$ Al filter to reduce the flux of lower energy X-rays, and hence minimise beam hardening (the undulator gap was reduced to a point where there were sufficient counts through the densest parts of a specimen). A PCO4000 camera with scientific grade $4008 \times 2672$ pixel CCD sensor was used to collect 18010.3 second projections on a $4 \times$ objective for lower resolution scans (providing voxel sizes of $1.1 \mu \mathrm{m}$ ), and 36000.5 second projections using a $10 \times$ objective (providing voxel sizes $0.45 \mu \mathrm{m}$ respectively). Further scans were collected with a $28 \mathrm{keV}$ monochromatic source, and 10× objective, reduced $\mathrm{Al}$ 
filter (0.2mm thickness), and 2 second exposure to collect data without beam hardening. All projections employed an X-ray sensitive scintillator emitting visible light (cadmium tungstate), and volumes were reconstructed using in-house filtered back projection reconstruction algorithm (Titarenko et al. 2010).

Volumes were visualised using both volume and surface rendering. For both forms of visualisation, tiff stacks (DLS) or VGI/VOL files (MXIF) were loaded using Drishti import, the histograms examined and correctly windowed prior to conversion to 8 bit grayscale data. These were either exported as Drishti volumes (.pvl.nc), or as PNG stacks for the SPIERS software suite. Volume rendering was conducted in Drishti (Limaye 2012), which can render data based on a two dimensional (value-gradient magnitude) histogram. A transfer function was used to select, and then render, different regions of this histogram in three dimensions: for this work, different phases were selected using multiple transfer functions - typically to pick out the rock exterior, oxide phases of medium X-ray attenuation, as well as the densest arsenide and PGM inclusions. These transfer functions were copied between datasets and modified as required. Visualisations were also conducted in SPIERS following the methods of Garwood and Sutton (2010) and Sutton et al. (2012), and subsequently rendered using the open source Raytracer Blender (see Garwood and Dunlop 2014).

\section{Results}

\section{Petrographic observations}

Aspects of the petrography and mineralogy of the Cliff chromitites have been previously described by Prichard and Tarkian (1988), Prichard et al. (1994) and Derbyshire et al. (2013), and we focus here on new observations that bear directly on the microstructural distribution of Ni-arsenide and PGM. The Cliff chromitites contain 50-90 vol.\% Cr-spinel, in a groundmass composed predominantly of lizardite (Figs. 3a, 3b). The Cr-spinel forms subhedral-anhedral crystals and aggregates of crystals that are heavily fractured (Fig. 4a). Many of the larger fractures continue into 
the groundmass serpentinite (Fig. 3c). Chrome-spinel crystal edges and the interiors of intra-Crspinel fractures are typically lined with selvedges of sieve-textured ferrian chromite (although some of this material is also likely to be non-stoichiometric ferritchromit, as noted by Derbyshire et al. 2013), with extensive further (exterior) rimming of ferrian chromite rims by a chloritic mineral (Figs. 3a, 3b). The chlorite-like rims are typically about 10-20 $\mu \mathrm{m}$ thick, and in addition to occurring on grain edges, they line serpentinised inclusions within $\mathrm{Cr}$-spinel grains (e.g., Fig. 3b) and fill intra-Cr-spinel fractures (Fig. 3b). The Fe-rich rims and ferrian chromite deposited within intra-crystal fractures are compositionally heterogeneous (composite) (Fig. 4b), suggesting that the alteration of primary $\mathrm{Cr}$-spinel occurred in multiple stages. Base-metal sulphides are rare to completely absent in Cliff chromitite samples.

Nickel-arsenide is present in accessory abundances, with grain sizes that are typically 20 to $50 \mu \mathrm{m}$ in diameter. Grains of Ni-arsenide $<5 \mu \mathrm{m}$ in size are not common. The Ni-arsenides are consistently situated close to $\mathrm{Cr}$-spinel grain boundaries and within intra-Cr-spinel fractures and alteration zones (Figs. 4b, 4c), often in small clusters or linear trains of crystals comprising less than 10 visible grains (e.g., Fig. 4c). Thus, there is a close textural association between Ni-arsenide and the ferrian chromite. Isolated larger grains of $\mathrm{Ni}$-arsenide are also less commonly observed within the groundmass (Fig. 4a). A critically important microstructural observation is that the visible PGM in the Cliff chromitite are spatially correlated with the Ni-arsenide and ferrian chromite (Figs. 4d, 4e, 4f). The PGM are typically $\leq 5 \mu \mathrm{m}$ in diameter and EDS analysis suggests that many of the 'bright' phases analysed below this size threshold are PGM. However, the majority of grains are much smaller than this, meaning that quantitative determination of their compositions using the electron microprobe is not possible. The PGM observed may occur either as inclusions within $\mathrm{Ni}$-arsenides, attached to the edges of Ni-arsenides (e.g., Fig. 4f), or in close proximity to them.

\section{Mineral compositional data}


The Ni-arsenides at Cliff predominantly comprise maucherite $\left(\mathrm{Ni}_{11} \mathrm{As}_{8}\right)$, with subsidiary orcelite $\left(\mathrm{Ni}_{5-\mathrm{x}} \mathrm{As}_{2}\right)$. Prichard et al. (2004) and Derbyshire et al. (2013) have also reported nickeline (NiAs), as well as accessory godlevskite $\left([\mathrm{Ni}, \mathrm{Fe}]_{9} \mathrm{~S}_{8}\right)$, millerite $(\mathrm{NiS})$ and heazlewoodite $\left(\mathrm{Ni}_{3} \mathrm{~S}_{2}\right)$. The maucherite and orcelite have $\sim 1$ wt.\% level impurities of S, Fe, Sb and Co. Systematic compositional variation is not observed in the minor elements present in the $\mathrm{Ni}$-arsenides, with the exception of S, which exhibits a weak negative correlation with Ni content (Fig. 5). The Cliff PGM assemblage comprises sperrylite $\left(\mathrm{PtAs}_{2}\right)$, stibiopalladinite $\left(\mathrm{Pd}_{5} \mathrm{Sb}_{2}\right)$ and irarsite ([Ir, $\left.\left.\mathrm{Ru}, \mathrm{Rh}, \mathrm{Pt}\right] \mathrm{AsS}\right)$, with subordinate laurite $\left(\mathrm{RuS}_{2}\right)$, confirming and extending the observations of Tarkian and Prichard (1987), Prichard and Tarkian (1988) and Prichard et al. (1994). Other PGM reported from Cliff by Tarkian and Prichard (1987) and Prichard and Tarkian (1988) include hongshiite (PtCu), potarite $(\mathrm{PdHg})$ and hollingworthite (Rh,Pt,Pd)AsS, but these phases were not observed here. The Ru-rich pentlandite reported by the latter authors was also not observed here. The compositional variation of the Cliff PGM population analysed in the current study is illustrated in Figure 6. The sperrylite at Cliff is characterised by $\mathrm{S}, \mathrm{Fe}, \mathrm{Sb}$ and $\mathrm{Ir}$ impurities. Stibiopalladinite shows some intergrain compositional variation, with $\mathrm{Fe}, \mathrm{As}, \mathrm{Cu}$ and $\mathrm{Pt}$ present in up to wt.\% concentrations. Irarsite contains sub wt.\% levels of $\mathrm{Cu}, \mathrm{Fe}$ and $\mathrm{Sb}$. The single grain of laurite analysed has a relatively high As concentration ( 3 wt.\%), with measurable Os (>1 wt.\%) and Rh ( 4 wt.\%) concentrations. Covariation of certain elements is observed between different PGM groups (e.g., Rh versus S; Fig. 6a), that might suggest that the PGM behaved as a single paragenesis, or a sequence of parageneses, and there is overlap between irarsite, sperrylite and stibiopalladinite in Ni versus Fe space (Fig. 6b). In other respects (e.g., Fe versus Pt, Fig. 6c; Ir versus As, Fig. 6d), the different phases are clearly distinguished from one another and compositional variation within mineral groups is also observed. Stibiopalladinite shows a weak trend of sympathetically increasing $\mathrm{Cu}$ with $\mathrm{Pt}$ (Fig. 6e) and sperrylite and irarsite show a negative correlation between $\mathrm{Sb}$ and $\mathrm{As}$ (Fig. 6f).

The LA-ICP-MS data indicate that the PGE are not hosted within the fresh Cr-spinel. Concentrations of $\mathrm{Co}, \mathrm{Zn}, \mathrm{As}$ and $\mathrm{Pb}$ are relatively high in $\mathrm{Cr}$-spinel (maximum concentrations of 
278, 428, 49 and $1.5 \mathrm{ppb}$, respectively). A positive correlation is observed between Co and Zn (Fig. 7a), as well as weaker, but sympathetic covariation of As with $\mathrm{Pb}$ and $\mathrm{Co}$ (Figs. 7b, 7c). Maucherite grains show weak positive correlations between base and precious metals in some cases (e.g., Au, Pt versus Cu; Figs. 8a, 8b), but not in others (e.g., Co versus Rh; Fig. 8c). Platinum and Pd are also positively correlated in maucherite (Fig. 8d). The LA-ICP-MS traverses from Cr-spinel through the ferrian chromite rims and into the groundmass give insights into the distribution of the PGE in the various mineral components, as well as other trace metals and semi-metals (Figs. 9a-c). The ferrian chromite rims contain elevated $\mathrm{Co}$ and $\mathrm{Ni}$ (and $\mathrm{Cu}$ and $\mathrm{Zn}$, not shown in Fig. 9), relative to fresh $\mathrm{Cr}$-spinel. Arsenic is also enriched in the sieve-textured rims, and follows the behavior of $\mathrm{Ni}$ particularly well. Cobalt (and Zn) concentrations are considerably lower in the serpentinite groundmass, but Ni and As are higher. The traverse shown in Figure 9c suggests that the distribution of $\mathrm{Ni}$ and $\mathrm{As}$ in the serpentinite groundmass is relatively uniform, indicating either abundant pervasively disseminated fine-grained Ni-arsenides, or another mode of occurrence. In most cases, the PGE are indistinguishable from background levels within Cr-spinel grains, with the exception of obvious inclusions of Ni-arsenide (e.g., Fig. 9a). However, in some samples the altered Cr-spinel rims contain elevated Os and Pd (Figs. 9b, 9c). The serpentinite groundmass around some $\mathrm{Cr}$-spinel crystals contains concentrations of Os, Pd and to a lesser extent, Ru, which are significantly higher than background levels. Figure 9c indicates elevated levels of Os relatively homogeneously distributed throughout the groundmass. The distribution of $\mathrm{Pd}$ is more irregular, though given the lack of covariation of base-metals it is not clear if this is a mineralogical control (Fig. 9c). Platinum and Ir in the Cr-spinel, the altered rims and the groundmass serpentinite are generally indistinguishable from background along the traverses analysed.

\section{$X$-ray microtomography}

The X-ray microtomography analyses provide insights into the spatial distribution of Ni-arsenides in the Cliff chromitites (Figs. 10, 11). In this study, Ni-arsenides have not been thresholded from 
PGM due to the similarities in grey levels of both mineral groups and the fact that the PGM are typically $<5 \mu \mathrm{m}$ in diameter. On the basis of the detailed textural observations, it is evident that they are distributed similarly. As such, conclusions drawn from X-ray microtomography on the microstructural relationships of the Ni-arsenide are broadly applied to the PGM too. The microtomography highlights that clusters of $\mathrm{Ni}$-arsenide (and PGM) are typically sited at the grain boundaries of Cr-spinel crystals (Figs. 11a,b,c), often at points where fractures in the crystals intersect the groundmass serpentinite. Such fractures extend into the serpentinite, and may control the distribution of Ni-arsenide grains that appear to be isolated in the groundmass (Figs. 11a,b). The microtomography data also highlight the considerable density of microfractures that cut through the Cr-spinel crystals (Fig. 11b), and subtly suggest that olivine pseudomorphs survive in the groundmass (Fig. 10c), hinting at the protolith texture and mineralogy prior to serpentinisation.

\section{Discussion}

\section{A low temperature Ni-arsenide-PGM paragenesis at Cliff}

The formation of ferrian chromite (plus ferritchromit) in ophiolite and komatiite chromitites has been attributed to low grade (greenschist-lower amphibolite facies) metamorphism of Cr-spinelbearing serpentinite (Kimball, 1990; Barnes and Roeder 2001; Mellini et al. 2005; GonzálezJiménez et al. 2009; Derbyshire et al. 2013). Barnes (2000) described the effects of metamorphic processes on the chemical composition of Cr-spinels from komatiites. In particular, Barnes concluded that $\mathrm{Fe}$ and $\mathrm{Zn}$ enrichment begins at greenschist facies, but continues on and is enhanced at amphibolite facies as magnetite replacement advances its encroachment on Cr-spinel crystal cores. There is a corresponding depletion in $\mathrm{Ni}$ during this process which occurs mostly at amphibolite grade. The stabilisation of chlorite (at $\sim 550^{\circ} \mathrm{C}$ ) plays a significant role in the mobility of $\mathrm{Al}^{3+}$ cations from $\mathrm{Cr}$-spinel above this temperature. At relatively low metamorphic grades (greenschist facies), Zn, Mn and Co enrichment in Cr-spinel is observed. The Cliff chromitites have sieve-textures and alteration occurring both along grain boundaries and intragrain fractures. This 
strongly suggests that a reactive fluid was responsible for the metamorphism of the Cr-spinels. A good correlation is observed between $\mathrm{Zn}$ and $\mathrm{Co}$ (Fig. 7a) in ferrian chromite, suggesting that these metals were mobile during metamorphism. In addition, As correlates positively with $\mathrm{Pb}$ and $\mathrm{Co}$, with the highest concentrations of these elements present in the ferrian chromite rims. This suggests that the fluids responsible for alteration of the Cr-spinel had a high As activity. The production of ferrian chromite is an oxidizing reaction, and has clearly also resulted in extensive precipitation of the chlorite mineral on Cr-spinel grain boundaries (Figs. 3a, 3b). Derbyshire et al. (2013) suggested that this phase was septechlorite, an aluminous serpentine, but $\mathrm{Cr}$-rich chlorite is also possible along the lines of a reaction such as: Cr-spinel + Antigorite $\rightarrow$ Fe-rich Cr-spinel + Cr-chlorite (Merlini et al. 2009). Further analyses of this mineral are required for a definitive identification.

The Ni-arsenide in the Cliff chromitites is dominated by maucherite, with subordinate orcelite and nickeline (Prichard and Lord, 1993; Derbyshire et al. 2013). Nickel-sulphide is conspicuous by its absence; by contrast, other Unst chromitites and their host dunites typically contain Ni-sulphide. The visible PGE mineralogy is dominated by arsenide phases, with a preponderance of sperrylite controlling the distribution of Pt in the Cliff chromitites. The Niarsenides and PGM are concentrated in the alteration zones and intra-crystal fractures of Cr-spinel crystals, especially where Cr-spinel is altered to sieve-textured ferrian chromite. We suggest this relationship implies that the reaction responsible for the formation of the ferrian chromite also involved the $\mathrm{Ni}$-arsenide, or perhaps the $\mathrm{Ni}$-arsenide was a product of that reaction. In addition, sulphide melts wet Cr-spinel surfaces much better than they do silicate mineral surfaces (Brenan and Rose 2002), so it seems reasonable to suggest that arsenide might behave similarly. Such behavior would explain the proximity of the bulk of the $\mathrm{Ni}$-arsenide grains to $\mathrm{Cr}$-spinel in these samples. The novel X-ray tomography data presented here demonstrates that the Cliff chromitites are pervasively deformed; the constituent Cr-spinels preserve evidence for complex fracturing and alteration at sub-grain length-scales. Fluids were clearly focused along these intra-grain fractures leading to precipitation of the PGM (Fig. 4d). This observation conclusively demonstrates a late- 
stage (and presumably low-temperature, compared to chromitite formation) origin for the style of precious metal enrichment at Cliff. The three major PGM observed here (sperrylite, irarsite and stibiopalladinite) do not occur in different microstructural positions to one another, i.e., all are observed as inclusions in $\mathrm{Ni}$-arsenide, sited along $\mathrm{Cr}$-spinel fractures and at $\mathrm{Cr}$-spinel grain boundaries (e.g., Fig. 4c). This suggests that all are part of the same paragenesis, and that they are coeval with the Ni-arsenide and the ferrian chromite. The broad variability of mineral compositions measured by electron microprobe (both in terms of base and precious metal abundances; Fig. 6) suggests that the processes responsible for their crystallisation occurred over either a range in temperature or from fluids with varying compositions. Maucherite is stable over a wide temperature interval (Fig. 12; Yund 1961), down to $\sim 200^{\circ} \mathrm{C}$, as is sperrylite. It therefore seems plausible that several generations of hydrothermal fluid were involved, to account for the complex microstructural relationships, intra-grain textures (e.g., Fig. $\mathbf{4 f}$ ) and the variation in PGM chemistry observed.

\section{Evidence for groundmass-hosted PGE enrichments}

The LA-ICP-MS traverses across Cr-spinel grain boundaries in the Cliff samples yield intriguing insights into the distribution of the PGE. The serpentinite groundmass contains concentrations of Os and Pd that are significantly higher than background, and that are impossible to spatially resolve as discrete PGM grains (e.g., Os in the traverse illustrated in Fig. 9c). The PGE data along these traverses might potentially be explained by abundant very fine grained Os-rich phases disseminated throughout the serpentinite. The whole rock Os concentration of the Cliff chromitites is $\sim 3 \mathrm{ppm}$ (O’Driscoll et al. 2012). As shown in Figure 9, this Os is not in the Cr-spinel, so there is apparently a significant (unidentified) Os carrier present, potentially a nuggeting or clustering effect of Os in the groundmass. Relatively high levels of Pd are also present throughout the groundmass serpentinite. The traverses also indicate that Pt levels in the serpentinite groundmass and the Crspinel are indistinguishable from background levels. This is satisfactorily explained by the relatively large grain size of sperrylite crystals throughout the samples, which presumably act as 
high concentration nodes for Pt and potentially account for the bulk rock concentration of up to 100 ppm (O’Driscoll et al. 2012).

\section{Arsenide as a collector of PGE at Cliff}

The potential importance of arsenide as a collector of the PGE in magmatic and hydrothermal systems has been well-documented (Hanley, 2007; Dare et al. 2010; Godel et al. 2012; Le Vaillant et al. 2015; Prichard et al. 2013; Helmy et al. 2013; Helmy and Bragagini 2017), and though arguably not completely understood, it is known that As-rich deposits can exhibit very high PGE grades. Arsenic is enriched in intermediate solid solution (iss) during cooling (Holwell and McDonald, 2010), and there is a broad spectrum of Pd and Pt-rich arsenide phases that attest to the ease at which bonding with the metals occurs. Indeed, although experimental evidence for the system is not extensive, $\mathrm{Pt}$ and $\mathrm{Pd}$ may have greater affinity for arsenide than for sulphide (Fleet at al. 1993; Wood 2003; Helmy et al. 2013). Helmy et al. (2013) conclude that Pt and Pd associate with $\mathrm{As}^{\mathrm{n}-}$ in preference to $\mathrm{S}^{2-}$ before saturation of arsenide in sulphide melts (perhaps as nano-metre sized As-metal clusters). The latter authors propose that the affinities of the precious and basemetals for an immiscible arsenide melt are: $\mathrm{Pt}>\mathrm{Pd}>\mathrm{Ni}>>\mathrm{Fe} \approx \mathrm{Cu}$. Pina et al. (2013) also reported that maucherite was strongly enriched in most chalcophile elements (including the PGE) relative to coexisting (co-paragenetic) sulphides (by factors of 10-10²). Many of the studies listed above have attributed As mobilisation to magmatic processes, such as incorporation of an As-rich assimilant into magma (Godel et al. 2012), or leaching of As from crustal rocks by hydrothermal fluids (Le Vaillant et al. 2015). Kiefer et al. (2017) have also attributed the formation of complex sulfarsenide and arsenide mineralisation in the Dobšiná deposit (Slovakia) to the activity of fluids operating at temperatures less than $200^{\circ} \mathrm{C}$. In the Bou Azzer ophiolite (southern Morocco), Ahmed et al. (2009) suggested mobilisation of As and Co from serpentinite to acidic (magmatic) fluids, at high fluidrock ratios. 
Generally, enrichments in As are not positively correlated with the PGE in the SOC

(Prichard and Lord 1993). The exception is the Cliff locality, where there are multiple potential sources for the As. Derbyshire et al. (2013) reported sulphides with hundreds to thousands of ppm of As in dunites and chromitites of other parts of the SOC. Heazlewoodite (more typically found in chromitite, such as at the Harold's Grave or Hagdale localities) has higher concentrations (>1000 $\mathrm{ppm}$ ) of As than dunite (in which pentlandite is dominant, $<500 \mathrm{ppm}$ ). Thus, reworking (alteration) of chromitite-hosted heazlewoodite could account for the As in the Cliff chromitites; the observation that Cliff is the only chromitite locality in the SOC where little or no sulphide is observed in most samples is intriguing and does suggest that local desulphurisation may have occurred in the chromitite. However, a similar process operating on sulphide-bearing mantle dunites such as those from The Viels (Derbyshire et al. 2013) might also be reasonable. In support of a desulphurisation process being important at Cliff, Helmy et al. (2013) note that sperrylite is stable relative to platarsite at relatively low sulphur activities.

It is also worth noting that Cliff is located close to the contact between the SOC and the underlying Neoproterozoic metasediments (Dalradian Supergroup). Immediately across the ophiolite contact (which is not the sole thrust, but a later structure referred to as the Burra Firth Lineament that represents a younger tectonic break; Cutts et al. 2011) are graphitic schists and limestones. Prichard and Lord (1993) reported high As concentrations in serpentinites along the Burra Firth Lineament (that they mistakenly refer to as the basal thrust). It is possible that the mineralisation at Cliff occurred during the reworking of the basal thrust that gave rise to the Burra Firth Lineament. Indeed, Hanley (2007) has previously suggested that graphitic schists might have acted as the source of As in the PGE-rich arsenide ores at Dundonald Beach South (Ontario, Canada). The Os isotope data of O'Driscoll et al. (2012) indicate that Cliff chromitites are more radiogenic $\left({ }^{187} \mathrm{Os} /{ }^{188} \mathrm{Os}_{\text {initial }}\right.$ of $\left.\sim 0.1292\right)$ than other SOC chromitites $(\sim 0.125)$, potentially supporting the role of a hydrothermal fluid that had interacted with the metasediments in the provision of the As. In fact, Prichard et al. (2017) recently reported variable Os isotope compositions for two PGM 
grains from Cliff $\left({ }^{187} \mathrm{Os} /{ }^{188} \mathrm{Os}\right.$ between 0.1270-0.1300), suggesting the presence of $>1$ PGM paragenesis, i.e., that the more radiogenic Os isotope compositions observed at Cliff may be controlled by a specific PGM paragenesis. In this scenario, which is our preferred interpretation, we envisage that As-rich fluids altered the existing sulphide assemblage in the Cliff chromitites, such that the high PGE concentrations probably reflect the original chromitite PGE budgets, albeit with reworking and upgrading of the PPGE in particular.

\section{Conclusions}

The SOC Cliff chromitite PGE occurrence is characterised by high PPGE relative to IPGE. Detailed investigations of the rocks reveal that unlike other SOC chromitites, there is little to no Ni-sulphide present. Instead, the primary ligand responsible for concentrating the PGE appears to have been As, as evidenced by the dominant PGM present (e.g., sperrylite and irarsite). Abundant Ni-arsenide and PGM are sited close to the edges of Cr-spinel crystals, and lining intra-crystal fractures. Together with observations that ferrian chromite and septechlorite formed coevally with the As-rich PGM paragenesis, it seems reasonable to suggest that a late-stage hydrothermal event has been responsible for remobilizing and upgrading the primary PGE abundances and distribution within the chromitites. The hydrothermal event could have resulted from movement on the Burra Firth Lineament, a structure that excised the ophiolite basal thrust in the region of Cliff. The source of the As is unknown, but may have come from Neoproterozoic metasediments on the opposite side of the Burra Firth Lineament, including graphitic schists and impure limestones. Recent studies that report relatively radiogenic chromitite Os isotope compositions from the Cliff area support the idea that a late-stage hydrothermal fluid, derived from crustal rocks, was involved.

\section{Acknowledgements}

BO'D would like to acknowledge support from the Manchester X-ray Imaging Facility (MXIF; Project \#405) at the University of Manchester, and the Manchester-Diamond collaboration is also 
acknowledged for beamtime at I13 (Project \# MT12201). B.O’D. also acknowledges support from a

Natural Environment Research Council (NERC) New Investigator grant NE/J00457X/1 and

Standard Grant NE/L004011/1 during the writing of this paper. Nick Edwards, Jennifer Anne, and

Joan Vila-Comamala are thanked for assistance at the Diamond Light Source Facility, and Tristan

Lowe for hosting the authors at MXIF. MXIF is funded in part by the EPSRC (grants

EP/F007906/1, EP/F001452/1 and EP/I02249X/1).

\section{References}

Ahmed, A.H., Arai, S. and Ikenne, M. (2009) Mineralogy and Paragenesis of the C-Ni arsenide ores of Bou Azzer, Anti-Atlas, Morocco. Economic Geology, 104, 249-266.

Barnes, S.J, (2000) Chromite in Komatiites II. Modification during greenschist to mid-amphibolite facies metamorphism. Journal of Petrology, 41, 387-409.

Barnes, S.J. and Roeder, P.L. (2001) The range of spinel compositions in terrestrial mafic and ultramafic rocks. Journal of Petrology, 42, 2279-2302.

Brenan, J.M., and Rose, L.A. (2002) Experimental constraints on the wetting of chromite by sulfide liquid. The Canadian Mineralogist, 40, 1113-1126.

Chew, D.M., Daly, J.S., Magna, T., Pagé, L.M., Kirkland, C.L., Whitehouse, M.J. and Lam, R. (2010) Timing of ophiolite obduction in the Grampian orogen. Geological Society of America Bulletin, 122, 1787-1799.

Coggon, J.A., Nowell, G.M., Pearson, D.G., Lorand, J.-P., Oberthür, T. and Parman, S.W. (2011) The ${ }^{190} \mathrm{Pt}^{186}$ Os decay system applied to dating platinum-group element mineralization of the Bushveld Complex, South Africa. Chemical Geology, 302-303, 48-60.

Crowley, Q.G. and Strachan, R.A. (2015) U-Pb constraints on obduction initiation of the Unst Ophiolite: an oceanic core complex in the Scottish Caledonides? Journal of the Geological Society, London, 172, 279-282.

Cutts, K.A., Hand, M., Kelsey, D.E., and Strachan, R.A. (2011) P-T constraints and timing of Barrovian metamorphism in the Shetland Islands, Scottish Caledonides: implications for the structural setting of the Unst ophiolite. Journal of the Geological Society, London, 168, 1265-1284.

Dare, S.A.S., Barnes, S.-J., Prichard, H.M. and Fisher, P.C. (2010) The timing and formation of platinum-group minerals from the Creighton $\mathrm{Ni}-\mathrm{Cu}$-platinum-group element sulfide deposit, Sudbury, Canada: Early crystallization of PGE-rich sulfarsenides. Economic Geology, 105, 10711096.

Day, J.M.D., O'Driscoll, B., Strachan, R.A., Daly, J.S. and Walker, R.J. (2017) Identification of mantle peridotite as a possible Iapetan ophiolite sliver in south Shetland, Scottish Caledonides. Journal of the Geological Society, London, 174(1), 88-92. 
Derbyshire, E.J., O’Driscoll, B., Lenaz, D., Gertisser, R. and Kronz, A. (2013) Compositionally heterogeneous podiform chromitite in the Shetland Ophiolite Complex (Scotland): implications for chromitite petrogenesis and late-stage alteration in the upper mantle portion of a supra-subduction zone ophiolite. Lithos, 162-163, 279-300.

Fleet, M.E., Chryssoulis, S.L., Stone, W.E., and Weisener, G. (1993) Partitioning of platinum-group elements and $\mathrm{Au}$ in the $\mathrm{Fe}-\mathrm{Ni}-\mathrm{Cu}-\mathrm{S}$ system: Experiments on the fractional crystallization of sulfide melt. Contributions to Mineralogy and Petrology, 115, 36-44.

Flinn, D. (2001) The basic rocks of the Shetland Ophiolite Complex and their bearing on its genesis. Scottish Journal of Geology, 37, 79-96.

Flinn, D., Miller, J.A. and Roddom, D. (1991) The age of the Norwick hornblendic schists of Unst and Fetlar and the obduction of the Shetland ophiolite. Scottish Journal of Geology, 27, 11-19.

Garwood, R.J. and Sutton, M.D. (2010) X-ray micro-tomography of Carboniferous stemDictyoptera: New insights into early insects. Biology Letters, 6, 699-702.

Garwood, R.J. and Dunlop, J.A. (2014) The walking dead: Blender as a tool for palaeontologists with a case study on extinct arachnids. Journal of Palaeontology, 88(4), 735-746.

Godel, B. (2013) High resolution X-ray computed tomography and its application to ore deposits: case studies from Ni-Cu-PGE deposits. Economic Geology, 108, 2005-2019.

Godel, B. (2015) Platinum-Group Element Deposits in Layered Intrusions: Recent Advances in the Understanding of the Ore Forming Processes. In Charlier, B., Namur, O., Latypov, R. and Tegner, C., eds., Layered Intrusions: Springer Netherlands, p. 379-432.

Godel, B. and Barnes, S.-J. (2008) Image analysis and composition of platinum-group minerals in the J-M Reef, Stillwater Complex. Economic Geology, 103, 637-651.

Godel, B., Barnes, S.J., Barnes, S.-J. and Maier, W.D. (2010) Platinum ore in 3D: Insights from high-resolution X-ray computed tomography. Geology, 38(12), 1127-1130.

Godel, B., Gonzalez-Alvarez, I., Barnes, S.J., Barnes, S.-J., Parker, P. and Day, J. (2012) Sulfides and sulfarsenides from the Rosie Nickel Prospect, Duketon Greenstone Belt, Western Australia. Economic Geology, 107, 275-294.

González-Jiménez, J.M., Kerestedjian, T., Proenza, J.A. and Gervilla, F. (2009) Metamorphism of chromite ores from the Dobromirtsi Ultramafic Massif, Rhodope Mountains (SE Bulgaria). Geologica Acta, 7, 413-429.

González-Jiménez, J.M., Griffin, W.L., Gervilla, F., Proenza, J.A., O’Reilly, S.Y. and Pearson, N.J. (2014a) Chromitites in ophiolites: how, where, when, why? Part I. Origin and significance of platinum-group minerals. Lithos, 189, 127-139.

González-Jiménez, J.M., Griffin, W.L., Proenza, J.A., Gervilla, F., O’Reilly, S.Y., Akbulut, M., Pearson, N.J. and Arai, S. (2014b) Chromitites in ophiolites: how, where, when, why? Part II. The crystallisation of chromitites. Lithos, 189, 140-158. 
Hanley, J.J. (2005) The Aqueous Geochemistry of the Platinum-Group Elements (PGE) in Surficial, Low-T Hydrothermal and High-T Magmatic Hydrothermal Environments. In Mungall, J.E., ed., Exploration for Platinum-Group Element Deposits, Mineral Association of Canada, Quebec, QC, Canada, P. 35-56.

Hanley, J.J. (2007) The role of arsenic-rich melts and mineral phases in the development of high grade $\mathrm{Pt}-\mathrm{Pd}$ mineralization within komatiite-associated magmatic $\mathrm{Ni}-\mathrm{Cu}$ sulfide horizons at Dundonald Beach South, Abitibi Subprovince, Ontario, Canada. Economic Geology, 102, 305-317.

Helmy, H.M., Ballhaus, C., Fonseca, R.O.C., and Nagel, T.J. (2013) Fractionation of platinum, palladium, nickel, and copper in sulfide-arsenide systems at magmatic temperature. Contributions to Mineralogy and Petrology, 166, 1725-1737.

Helmy, H.M. and Bragagini, A. (2017) Platinum-group elements fractionation by selective complexing, the $\mathrm{Os}, \mathrm{Ir}, \mathrm{Ru}, \mathrm{Rh}$-arsenide-sulfide systems above $1020^{\circ} \mathrm{C}$. Geochimica et Cosmochimica Acta, in press.

Holwell, D.A. and McDonald, I. (2010) A Review of the Behaviour of Platinum Group Elements within Natural Magmatic Sulfide Ore Systems. Platinum Metals Review, 54, 26-36.

Irvine, T.N. (1977) Origin of chromitite layers in the Muskox intrusion and other stratiform intrusions: A new interpretation. Geology, 5, 273-277.

Karup-Møller, S., Mackovicky, E. and Barnes, S.-J. (2008) The metal-rich portions of the phase system $\mathrm{Cu}-\mathrm{Fe}-\mathrm{Pd}-\mathrm{S}$ at $1000{ }^{\circ} \mathrm{C}, 900{ }^{\circ} \mathrm{C}$ and $725^{\circ} \mathrm{C}$ : implications for mineralization in the Skaergaard intrusion. Mineralogical Magazine, 72, 941-951.

Ketcham, R. A. and Carlson, W. D. (2001) Acquisition, optimization and interpretation of X-ray computed tomographic imagery: applications to the geosciences. Computers and Geosciences, 27, 381-400.

Kiefer, S., Majzlan, J., Chovan, M. and Števko, M. (2017) Mineral compositions and phase relations of the complex sulfarsenides and arsenides from Dobšiná (Western Carpathians, Slovakia). Ore Geology Reviews, 89, 894-908.

Kimball, K. (1990) Effects of hydrothermal alteration on the composition of chromian spinels. Contributions to Mineral Petrology, 105, 337-346.

Latypov, R., O’Driscoll, B. and Lavrenchuk, A. (2013) Towards a model for an in situ origin for PGE reefs in layered intrusions: insights from the chromitite seams of the Rum Eastern Layered Intrusion, Scotland. Contributions to Mineral Petrology, 166, 309-327.

Le Vaillant, M., Barnes, S.J., Fiorentini, M.L., Miller, J., McCuaig, T.C. and Muccilli, P. (2015) A hydrothermal Ni-As-PGE geochemical halo around the Miitel komatiite-hosted nickel sulfide deposit, Yilgarn Craton, Western Australia. Economic Geology, 110, 505-530.

Limaye, A. (2012) Drishti: a volume exploration and presentation tool. In: SPIE Optical Engineering+ Applications. International Society for Optics and Photonics, pp. 85060X-85060X.

Melcher, F., Grum, W., Simon, G., Thalhammer, T.V. and Stumpfl, E.F. (1997) Petrogenesis of the ophiolitic giant chromite deposits of Kempirsai, Kazakhstan: a study of solid and fluid inclusions in chromite. Journal of Petrology, 38, 1419-1458. 
Mellini, M., Rumori, C. and Viti, C. (2005) Hydrothermally reset magmatic spinels in retrograde serpentinites: formation of 'ferritchromit' rims and chlorite aureoles. Contributions to Mineralogy and Petrology, 149, 266-275.

Merlini, A., Grieco, G. and Diella, V. (2009) Ferritchromit and chromium-chlorite formation in melange-hosted Kalkan chromitite (Southern Urals, Russia). American Mineralogist, 94, 14591467.

Mungall, J.E. and Brenan, J.M. (2014) Partitioning of platinum-group elements and Au between sulfide liquid and basalt and the origins of mantle-crust fractionation of the chalcophile elements. Geochimica et Cosmochimica Acta, 125, 265-289.

Naldrett, A.J. and Duke, J.M. (1980) Platinum metals in magmatic sulfide ores. Science, 208, 14171424.

O’Driscoll, B., Day, J.M.D., Daly, J.S., Walker, R.J. and McDonough, W.F. (2009) Rheniumosmium isotope and platinum-group elements in the Rum Layered Suite, Scotland: Implications for Cr-spinel seam formation and the composition of the Iceland mantle anomaly. Earth and Planetary Science Letters, 286, 41-51.

O’Driscoll, B., Day, J.M.D., Walker, R.J., Daly, J.S., McDonough, W.F. and Piccoli, P.M. (2012) Chemical heterogeneity in the upper mantle recorded by peridotites and chromitites from the Shetland Ophiolite Complex, Scotland. Earth and Planetary Science Letters, 333-334, 226-237.

O’Driscoll, B. and González-Jiménez, J.M. (2016) Petrogenesis of the platinum-group minerals. Reviews in Mineralogy and Geochemistry, Mineralogical Society of America, 81, 489-578.

Oshin, I.O. and Crocket, J.H. (1986) Noble metals in the Thetford Mines ophiolites, Quebec, Canada. II. Distribution of gold, silver, iridium, platinum and palladium in the Lac de l'Est volcanosedimentary section. Economic Geology, 81, 931-945.

Page, N.J. and Talkington, R.W. (1984) Palladium, platinum, rhodium, ruthenium, and iridium in peridotites and chromites from ophiolite complexes in Newfoundland. Canadian Mineralogist, 22, 137-149.

Pina, R., Gervilla, F., Barnes, S.-J., Ortega, L. and Lunar, R. (2013) Partition coefficients of platinum group and chalcophile elements between arsenide and sulfide phases as determined in the Beni Bousera Cr-Ni mineralization (North Morocco). Economic Geology, 108, 935-951.

Prichard, H.M. (1985) The Shetland Ophiolite. In Gee, D.G. and Sturt, B.A. Eds., The Caledonide Orogen - Scandinavia and related areas. Wiley, New York, p. 1173-1184.

Prichard, H. and Tarkian, M. (1988) Platinum and Palladium minerals from two PGE-rich localities in the Shetland Ophiolite Complex. The Canadian Mineralogist, 26, 979-990.

Prichard, H.M. and Lord, R. (1993) An overview of the PGE concentrations in the Shetland Ophiolite Complex. Geological Society of London Special Publications, 76, 273-294.

Prichard, H.M., Ixer, R., Lord, R.A., Maynard, J. and Williams, N. (1994) Assemblages of platinum-group minerals and sulphides in silicate lithologies and chromite-rich rocks within the Shetland Ophiolite. The Canadian Mineralogist, 32, 271-294. 
Prichard, H.M., Fisher, P.C., McDonald, I., Knight, R.D., Sharp, D.R. and Williams J.P. (2013) The distribution of PGE and the role of Arsenic as a collector of PGE in the Spotted Quoll nickel ore deposit in the Forrestania Greenstone Belt, Western Australia. Economic Geology, 108, 1903-1921.

Prichard, H.M., Barnes, S. J., Godel, B., Halfpenny, A., Neary, C.R. and Fisher, P.C. (2015) The structure of and origin of nodular chromite from the Troodos ophiolite, Cyprus, revealed using high-resolution X-ray computed tomography and electron backscatter diffraction. Lithos, 218-219, 87-98.

Prichard H.M., Barnes S.J., Dale C.W., Godel B., Fisher P.C., Nowell, G.M. (2017) Paragenesis of multiple platinum-group mineral populations in Shetland ophiolite chromitite: 3D X-ray tomography and in situ Os isotopes. Geochimica et Cosmochimica Acta, in press.

Schouwstra, R.P., Kinloch, E.D. and Lee, C.A. (2000) A short geological review of the Bushveld Complex. Platinum Metals Review, 44, 33-39.

Spray, J.G. and Dunning, G.R. (1991) A U/Pb age for the Shetland Islands oceanic fragment, Scottish Caledonides: evidence from anatectic plagiogranites in 'layer 3' shear zones. Geological Magazine, 128, 667-671.

Sutton, M.D., Garwood, R.J., Siveter, D.J. and Siveter, D.J. (2012) Spiers and VAXML; A software toolkit for tomographic visualisation, and a format for virtual specimen interchange. Palaeontologia Electronica, 15(2), 14p.

Tarkian, M. and Prichard, H.M. (1987) Irarsite-hollingworthite solid-solution series and other associated Ru-, Os-, Ir- and Rh-bearing PGM's from the Shetland ophiolite complex. Mineralium Deposita, 22, 178-184.

Titarenko, V., Bradley, R., Martin, C., Withers, P. J. and Titarenko, S. (2010) Regularization methods for inverse problems in X-ray tomography. In: Developments in X-Ray Tomography VII (ed. Stock, S. R.) 7804, $40 Z$.

Wood, M. (2003) Arsenic in igneous systems: An experimental investigation: Unpublished B.A.Sc. thesis, Toronto, Ontario, Canada, University of Toronto, $32 \mathrm{p}$.

Yund, R.A. (1961) Phase relations in the system Ni-As. Economic Geology, 56, 1273-1296. 


\section{Figure Captions}

Figure 1. (a) Chondrite-normalised PGE patterns of various Shetland Ophiolite Complex chromitites, including Cliff, as well as other ophiolite chromitites. The chondrite normalization data are from Naldrett and Duke (1980).

Figure 2. Geological map of the Shetland Ophiolite Complex, illustrating the major components of the ophiolite as well as the chromitite localities (red dots) referred to in the text. Inset shows the regional position of the Shetland archipelago in the North Sea, relative to Scotland and Norway.

Figure 3. Cross-polarised light photomicrographs of Cliff chromitite, illustrating the development of chlorite rims on $\mathrm{Cr}$-spinel grain edges. (a) Large opaque grains are $\mathrm{Cr}$-spinel with blue-coloured chlorite rims. Chlorite is present in the groundmass too. (b) As above, except the development of chlorite rims around serpentinised olivine inclusions in Cr-spinel is evident, as well as the formation of chlorite along narrow intra-Cr-spinel fractures (arrowed). (c) Brittle deformation of $\mathrm{Cr}$-spinel aggregates in the Cliff chromitites, forming fractures infilled with fibrous chrysotile.

Figure 4. (a) Reflected light photomicrograph illustrating the typical texture of the Cliff chromitites. Note the highlighted 'bright' phases, which are Ni-arsenide, which may be located both at grain edges and isolated within the groundmass. (b) Back-scattered electron micrograph of a Crspinel grain showing complex resorption features, particularly at grain boundaries and along intragrain fractures. The presence of several $\mathrm{Ni}$-arsenide phases is highlighted. The dark grey $\mathrm{Cr}$-spinel at image centre is the fresh, unaltered composition. (c) Close-up back-scattered electron micrograph of Cr-spinel grain boundary. Note the development of ferrian chromite rims (lighter grey) at $\mathrm{Cr}$ spinel grain boundaries and along a narrow zone of alteration within the Cr-spinel crystal, and the presence of three sperrylite crystals in this zone. The large bright phase at the edge of the Cr-spinel is maucherite, as is the smaller phase below it. (d) Back-scattered electron micrograph illustrating a narrow intra-Cr-spinel fracture, containing numerous maucherite and sperrylite grains (bright phases). (e) Back-scattered electron micrograph of an area of complex alteration at the edge of a cluster of Cr-spinel crystals. Note the extensive development of sieve-textured ferrian chromite, and close spatial association of numerous $\mathrm{Ni}$-arsenide and PGM at the edges of the Cr-spinels and within the fractures that cross-cut the grains. (f) Close-up back-scattered electron micrograph of a maucherite grain, showing internal compositional heterogeneity, and (arrowed) an irarsite grain.

Figure 5. Plots of (a) S wt.\% versus Ni wt.\% and (b) Sb wt.\% versus As wt.\% in maucherite.

Figure 6. Plots of platinum-group mineral compositional variations (a) Rh wt.\% versus $\mathrm{S} w \mathrm{w} . \%$, (b) Ni wt.\% versus Fe wt.\%, (c) Fe wt.\% versus Pt wt.\%, (d) Ir wt.\% versus As wt.\%, (e) Pt wt.\% versus $\mathrm{Cu}$ wt.\%, (f) $\mathrm{Sb}$ wt.\% versus As wt.\%. See text for further discussion.

Figure 7. Plots of trace elements in $\mathrm{Cr}$-spinel as follows: (a) Zn versus $\mathrm{Co}$, (b) As versus $\mathrm{Co}$, (c) $\mathrm{Pb}$ versus As.

Figure 8. Plots of trace elements in Ni-arsenide as follows: (a) Au versus $\mathrm{Cu}$, (b) $\mathrm{Pt}$ versus $\mathrm{Cu}$, (c) Co versus Rh, (d) Pt versus Pd. See text for further discussion.

Figure 9. (a)-(c) Various time-resolved LA-ICP-MS traverses from Cr-spinel (dark grey) into serpentinised groundmass. The yellow colour represents background levels (i.e., laser off) and the white colour indicates data collection in the serpentinite groundmass. See text for further discussion. Specific features of the data referred to in the text are labeled on the panels. 
Figure 10. X-ray tomography data from the Cliff chromitites. (a) An example of the $\sim 1 \mathrm{~mm}$ diameter cores analysed by synchrotron. The dense phase coloured in light brown is Cr-spinel. (b) Hand specimen scanned at the MXIF facility, University of Manchester, using the Nikon Metris 225/320 kV Xray CT, showing the apparently random distribution of Ni-arsenides (false-colour purple grains) throughout the sample. (c) Cross section of a $\sim 1 \mathrm{~mm}$ diameter core, analysed by synchrotron. The partial outline of the core in plan view is shown by the white dashed line. The false-coloured light-brown phase is $\mathrm{Cr}$-spinel. Note the irregular amorphous grey features in the serpentinised groundmass, interpreted here to be relic (pseudomorphed) olivine grains.

Figure 11. X-ray tomography data from the Cliff chromitites. (a) False-coloured $\mu \mathrm{CT}$ scan showing Cr-spinel (light-brown) and clusters of Ni-arsenide grains (false-colour purple) sited at the point where a fracture network intersects the boundary between a $\mathrm{Cr}$-spinel grain and the serpentinised groundmass. (b) False-coloured image highlighting the abundance and complexity of fracturing of Cr-spinel grains (coloured green). Note the presence of high-density phases (Ni-arsenides) coloured purple, again sited within or close to intra-Cr-spinel fractures. (c) Close-up image of a Ni-arsenide (maucherite) entirely enclosed in the serpentinite groundmass - such occurrences tend to exhibit the coarsest grainsizes of $\mathrm{Ni}$-arsenide (light-brown is $\mathrm{Cr}$-spinel and purple is $\mathrm{Ni}$-arsenide).

Figure 12. Sketch of the temperature-composition phase diagram for the Ni-As system, reproduced from Yund (1961). The dashed lines indicate work not determined by that study. Mineral phase abbreviations as follows; ma: maucherite, nc: niccolite, rm: rammelsbergite, prm: pararammelsbergite. 
Figure 1

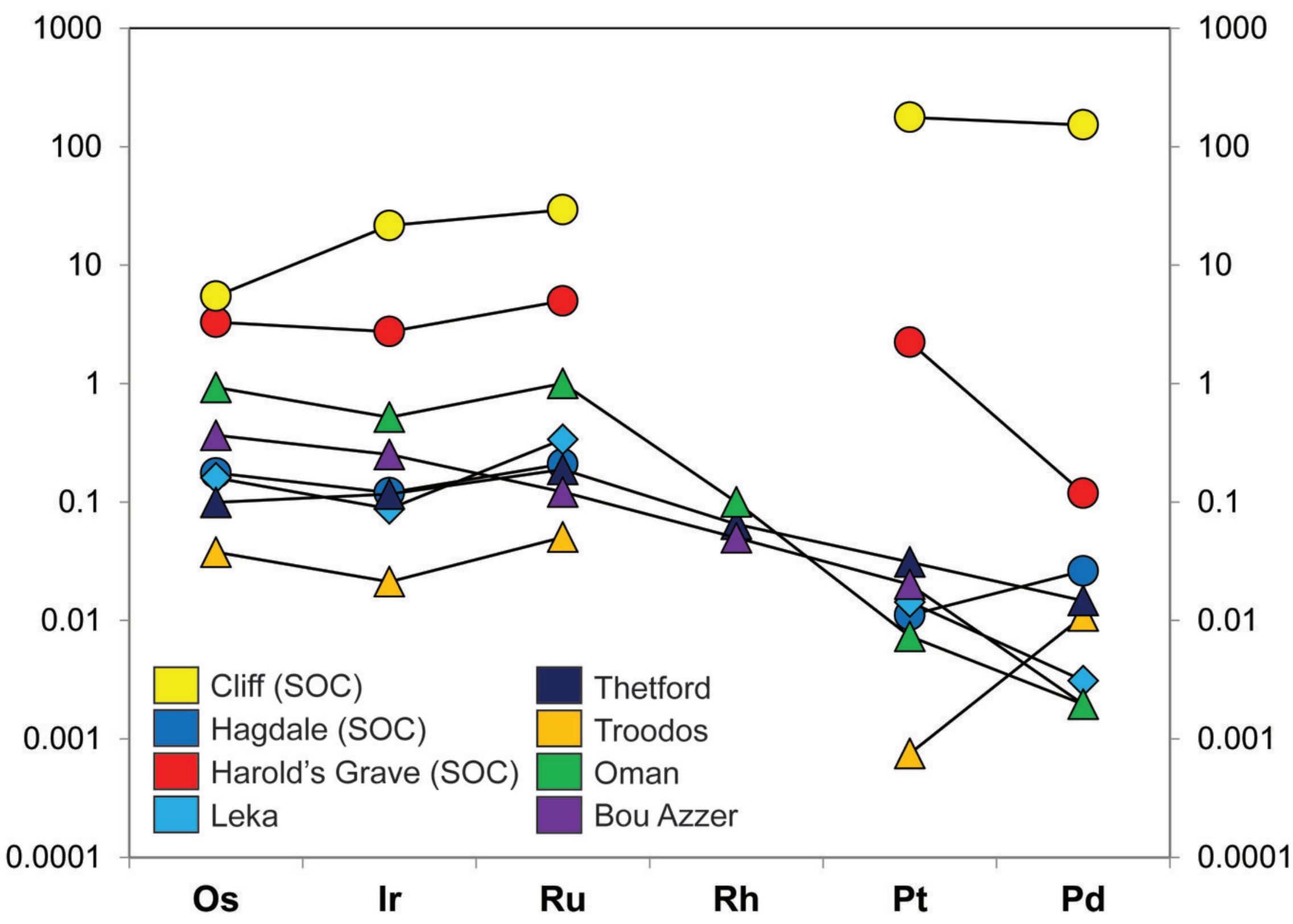



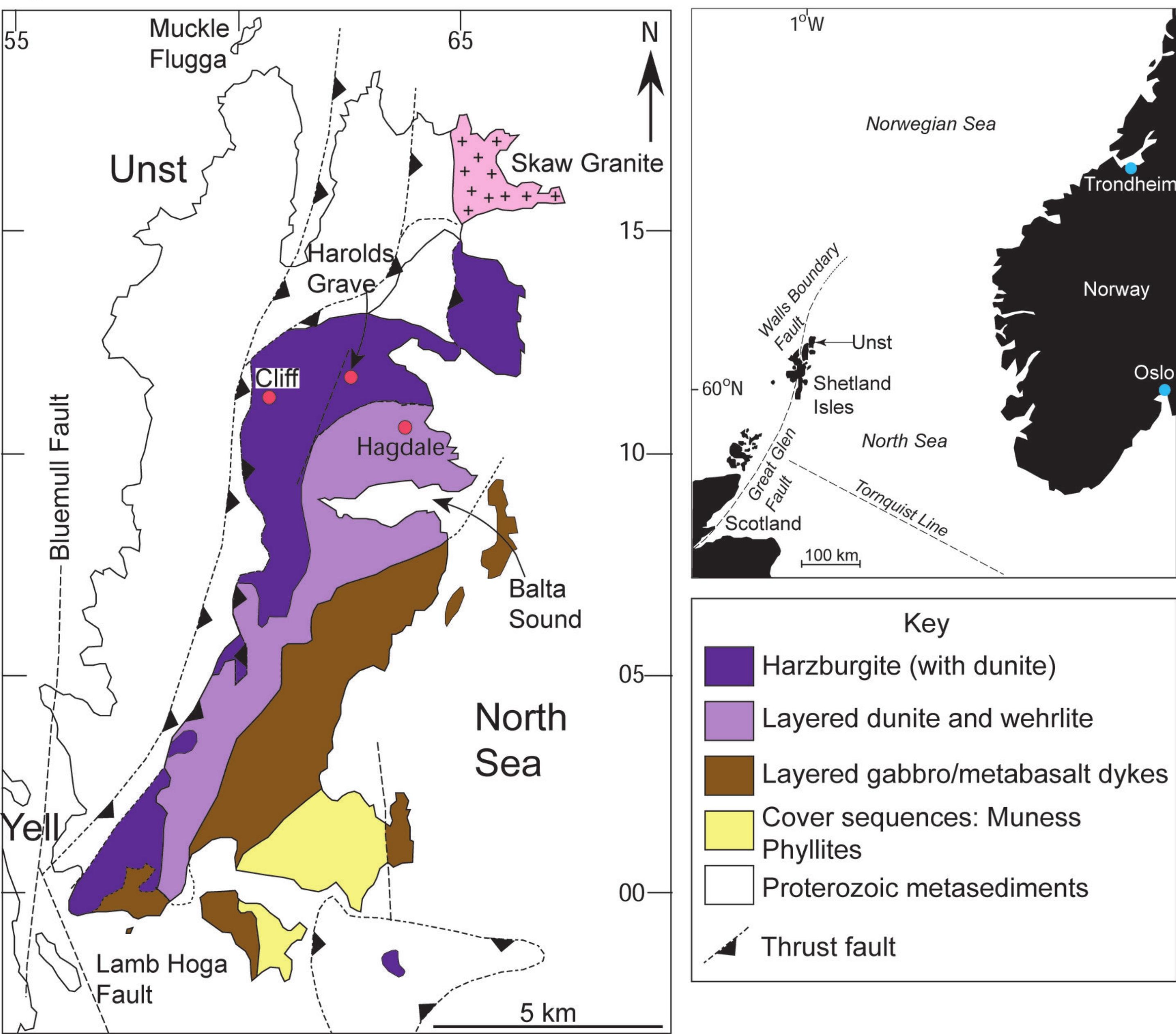

Key

Harzburgite (with dunite)

Layered dunite and wehrlite

Layered gabbro/metabasalt dykes

Cover sequences: Muness

Phyllites

$\square$ Proterozoic metasediments

Thrust fault 
Figure 5
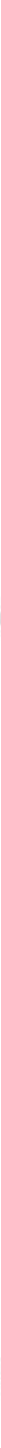


\section{Figure 6}
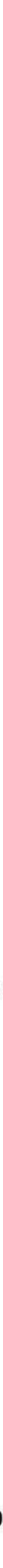
Figure 8
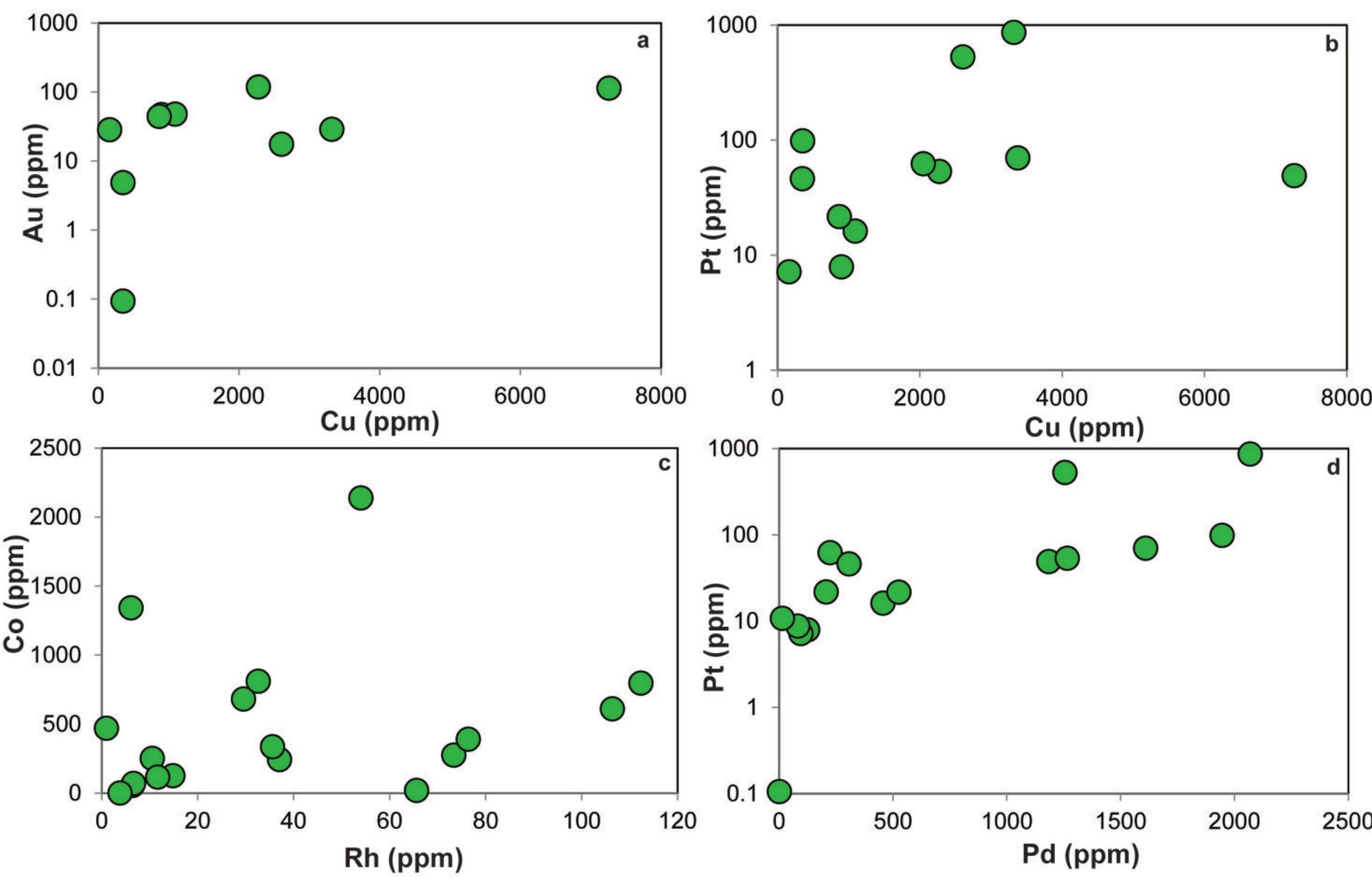

Pd (ppm) 


\section{Figure 9}
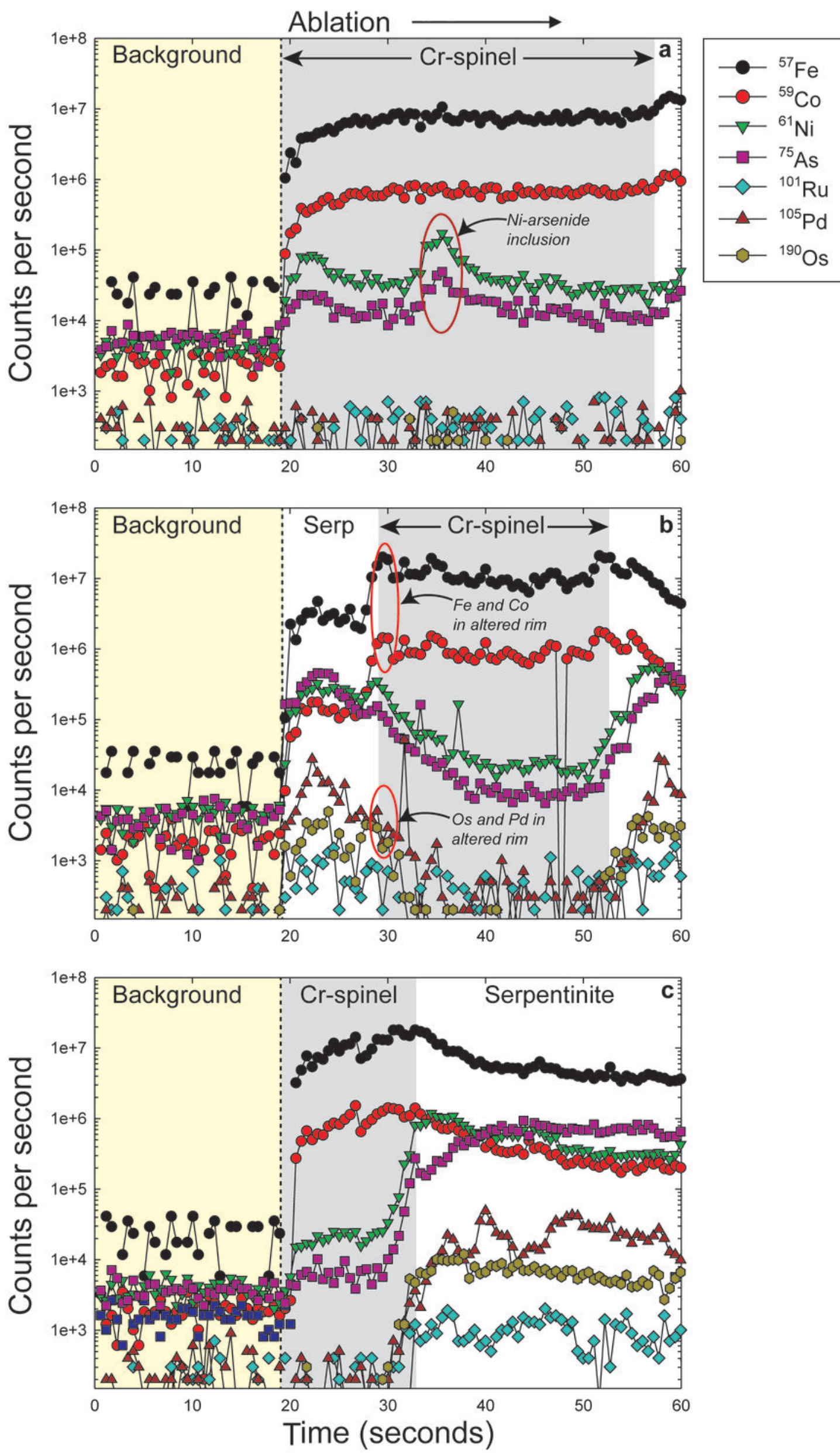
Figure 11

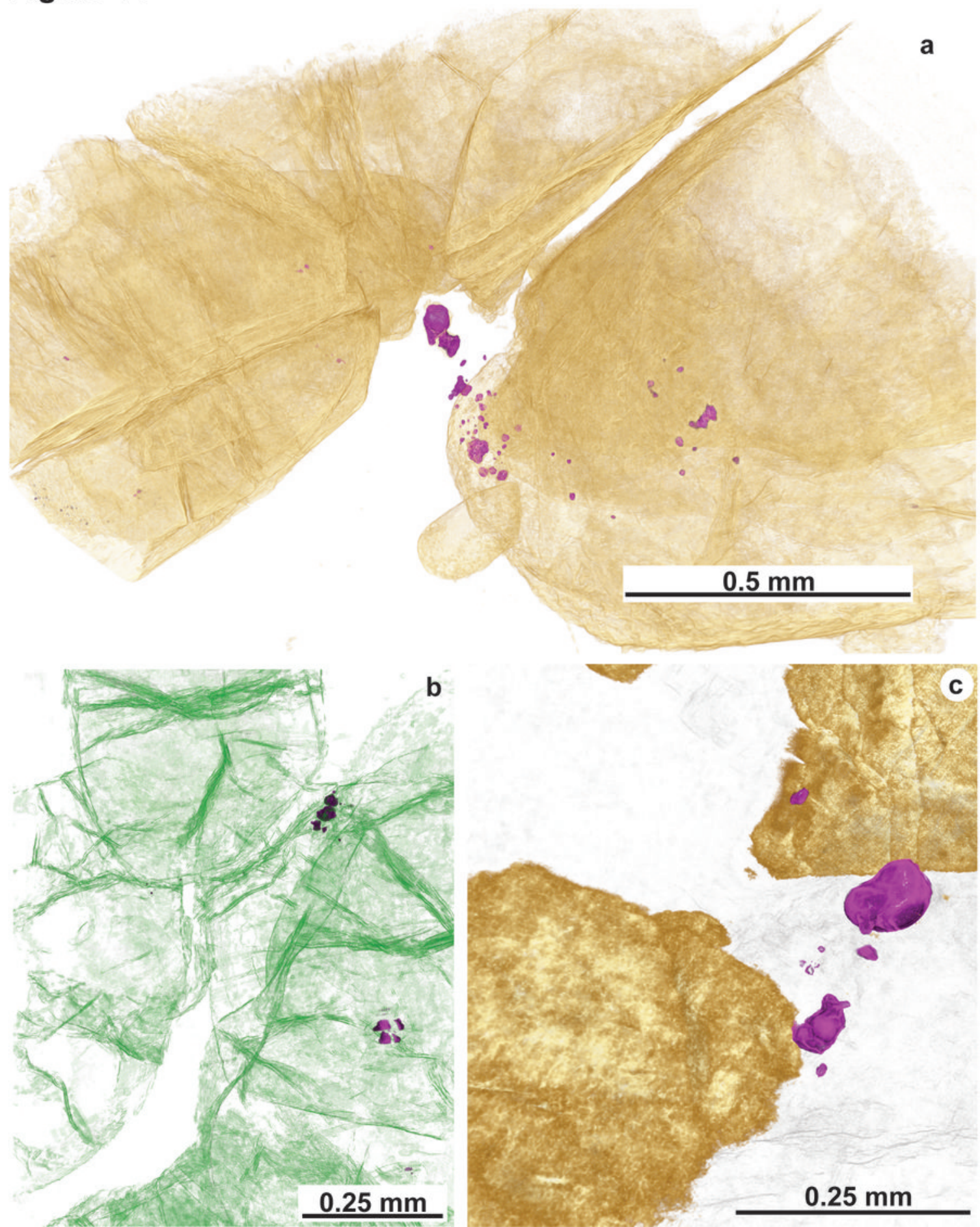




\section{Figure 12}

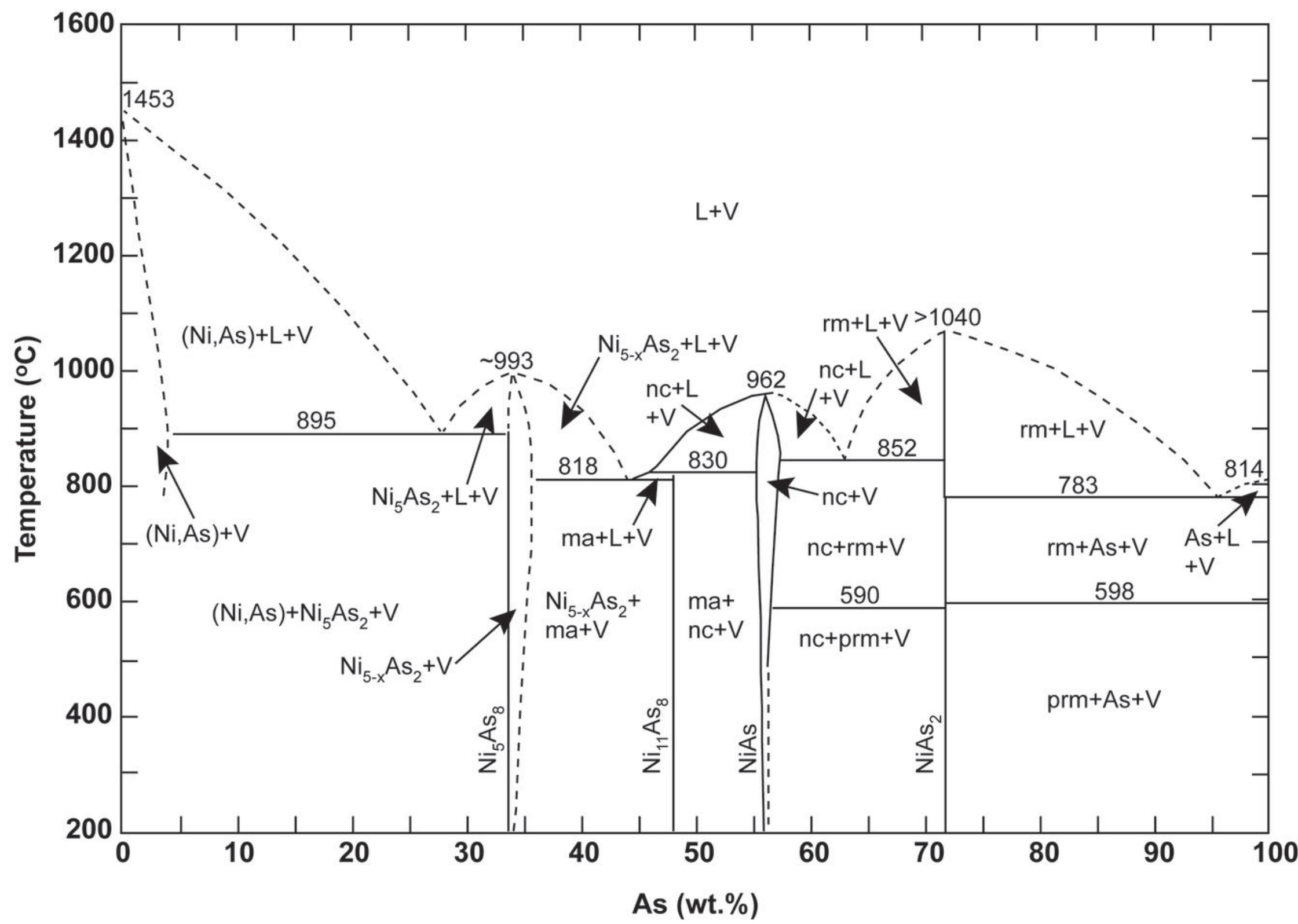

